\title{
Occult Lung Large Cell Carcinoma
}

National Cancer Institute

\section{Source}

National Cancer Institute. Occult Lung Large Cell Carcinoma. NCI Thesaurus. Code C6685.

A large cell lung carcinoma detectable by sputum cytology only. The primary tumor is undetectable radiographically or during bronchoscopy; therefore, it can not be assessed. 